\title{
Model Gaya Kepemimpinan dalam Kelompok Musik Kiai Kanjeng
}

\author{
Muhammad Tahdianoor \\ Program Pascasarjana Institut Seni Indonesia Yogyakarta \\ tahdianoor@gmail.com
}

\begin{abstract}
Abstrak
Banyak faktor yang membuat Kiai Kanjeng memiliki banyak prestasi. Salah satu faktor pentingnya adalah gaya kepemimpinan Emha Ainun Nadjib (Cak Nun) dalam memimpin Kiai Kanjeng. Karena itu peneliti tertarik untuk mengidentifikasi karakteristik gaya kepemimpinan dan merumuskan model gaya kepemimpinan Cak Nun dalam memimpin Kiai Kanjeng. Metode penelitian yang digunakan peneliti adalah kualitatif. Hasil analisis data berdasarkan teori gaya kepemimpinan dengan pendekatan studi kasus. Pengambilan data dilakukan dengan cara observasi, dokumentasi dan mewancarai beberapa narasumber yang dianggap penting dalam penelitian ini. Berdasarkan analisa data dalam penelitian ini, karakteristik gaya kepemimpinan yang identik dengan Cak Nun secara keseluruhan cenderung memenuhi katagori gaya kepemimpinan transformasional. Gaya kepemimpinan Cak Nun yang berbeda-beda berimplikasi pada kesolidan anggota, kreatif, eksis dan mempunyai penggemar yang militan sehingga Kiai Kanjeng mampu bertahan sampai sekarang. Model gaya kepemimpinan Kiai Kanjeng yang dipimpin oleh Cak Nun yaitu, otokrasi, demokrasi, kendali bebas (laissez faire) dan partisipatif, tergantung pada kegiatan Kiai Kanjeng.
\end{abstract}

Kata kunci: Kiai Kanjeng, pemimpin, gaya kepemimpinan, transformasional.

\begin{abstract}
Kiai Kanjeng from a standing start (1993) to the present (2016) already has been many achievements. It is the result of the leadership style by Emha Ainun Nadjib (Cak Nun) led Kiai Kanjeng. Thus the researchers are interested in identifying the characteristics of leadership style and formulate a model of leadership style in leading Cak Nun Kiai Kanjeng. Bernard M. Bass suggests that transformational leadership is the leader to encourage, motivate and innovate the members to do something beyond their own ability to improve the life of the group. The method used is a qualitative researcher. The results of data analysis are based on the theory of leadership style with a case study approach. Further data collection is done by observation, documentation and interviewed several sources that are considered in this study. Based on data analysis in this study, the characteristics of leadership style that is synonymous with Cak Nun meet category leadership style autocracy, democracy, free rein (laissez faire), participative and transformational in accordance with the activity. Cak Nun's leadership style is different implications for the solidity member, creative, exist and has fans that are militants so Kiai Kanjeng is able to survive until now. Cak Nun implements smoking-control leadership style transformational in schedulingduration exercise, discipline personnel and development staff resources (managerial). Cak Nun applies autocrary-transformational leadership style in addressing the invitation and when determining the strat-stoping song and song capabilities in the development ao leadsingger and composition/arrangement. Cak Nun apply transformational leadership style, autocrary and democratic in prepariation for staging. Cak Nun implements free rein, democratic, transformational leadership style when staging evaluation. Overall, there is a leadership style that is the same in each process, the transformational leadership style.
\end{abstract}

Keywords: Kanjeng Kiai, a leader, leadership styles, transformational. 


\section{Pendahuluan}

Kesuksesan dan kegagalan sebuah kelompok sangat dipengaruhi oleh cara pemimpin dalam memimpin. Gaya kepemimpinan dapat mempengaruhi budaya organisasi, eksistensi, prestasi, keberlanjutan dan perkembangan secara individu maupun kelompok. Hal ini juga berlaku bagi kelompok seni pertunjukan. Salah satu kelompok seni pertunjukan di Yogyakarta yang memiliki rekam jejak cukup panjang adalah Kiai Kanjeng. Kelompok ini dipimpin oleh Emha Ainun Nadjib atau yang akrab disapa Cak Nun. Di bawah kepemimpinannya Kiai Kanjeng menjadi cukup populer di tengah masyarakat, baik itu masyarakat umum maupun masyarakat seni. Cak Nun dengan gaya kepemimpinannya membuktikan bahwa Kiai Kanjeng yang mengusung konsep musik yang tidak mengikuti arus utama (mainstream) dapat bisa diterima oleh segala lapisan masyarakat walaupun di tengah derasnya industri musik yang kian terus berkembang, baik dari dalam bahkan luar negeri.

Dalam www.Kiaikanjeng.com, Cak Nun bersama Kiai Kanjeng sebagai kelompok musik yang kreatif dan produktif, terhitung sejak Juni 1998 hingga Desember 2006, telah melakukan konser lebih dari 22 propinsi, 376 kabupaten, 1.430 kecamatan, dan 1.850 desa di seluruh pelosok Indonesia. Sejak tahun 2007 hingga sekarang (2016) Cak Nun dan Kiai Kanjeng secara rutin pentas setiap bulan, tepatnya setiap tanggal 17 yang dihadiri oleh ribuan para jemaah di Tamantirto, Kecamatan Kasihan, Kabupaten Bantul.

Tidak hanya konser di dalam negeri saja, namun kerap juga diundang ke berbagai belahan dunia lainnya yaitu tur konser ke 6 kota di Mesir, Malaysia, Berunai Darussalam, hingga rangkaian acara di Eropa: Inggris (Leeds, London, Manchester dan Bermingham), Jerman dan Skotlandia Dari 2007 hingga 2016 prestasi Kiai Kanjeng dapat dikatakan setabil. Kiai Kanjeng telah melaksanakan pementasan di beberapa negara seperti Maroko, Itali, Belanda, Jerman, Hongkong dan Malaysia (www.Kiaikanjeng.com). Seorang etnomusikolog asal Amerika bernama Aniras Musen menjadikan Kiai Kanjeng sebagai objek penelitian. Hal tersebut mebuktikan bahwa Kiai Kanjeng adalah kelompok musik yang berpengaruh di bidangnya.

Rekam jejak Kiai Kanjeng seperti dijelaskan di depan, tentu tak lepas dari gaya Cak Nun sebagai pemimpin. Cak Nun yang dikenal sebagai budayawan yang relegius membawa Kiai Kanjeng tak hanya sebagai media dakwah agama Islam, namun juga sebagai penghibur. Warsana menyatakan, Kiai Kanjeng tidak hanya sebagai media dakwah agama Islam, namun Kiai Kanjeng juga dapat berdiri sendiri sebagai seni, misalnya tampil dalam acara Festival Jazz di Jakarta. Gaya kepemimpinannya mengantarkan Kiai Kanjeng menjadi kelompok musik yang sangat berpengaruh. Gaya kepemimpinannya tersebut tentu menarik untuk diteliti, karena gaya kepemimpinan Cak Nun membuat para anggotanya (pemusik, vokalis, kru, dan kemanajerialan) merasa nyaman bekerja sama maupun menerima tugas demi mewujudkan cita-cita kelompok. Hal tersebut dapat diamati melalui dokumentasi yang tersedia di www.kiaikanjeng.com. Sehingga Kiai Kanjeng menjadi salah satu kelompok musik yang berkualitas secara karya dan mempunyai nama yang cukup besar, baik di dalam maupun di luar negeri. Berdasarkan hal-hal di atas, maka peneliti tertarik mengidentifikasi permasalahan, menganalisis, dan merumuskan model kepemimpinan kelompok musik Kiai Kanjeng yang akan berkontribusi terhadap dunia akademik maupun praktis. 


\section{Metode Penelitian}

\section{a. Wawancara}

Wawancara merupakan teknik yang dilakukan dengan cara berdialog dengan menggunakan beberapa pertanyaan terkait sikap, perilaku, tindakan Cak Nun yang terkait gaya kepemimpinan dengan beberapa narasumber, misalnya peneliti dengan beberapa pemusik tetap dan/atau additional player (pemusik pengganti dan/atau tambahan), bagian pengelola (admin) dan para kru kelompok musik Kiai Kanjeng bahkan juga melibatkan para penonton sebagai teknik konfirmasi antara narasumber.

Tabel 1.1 Subyek Penelitian berupa Wawancara

\begin{tabular}{|l|l|l|l|l|}
\hline No & \multicolumn{1}{|c|}{ Nama } & \multicolumn{1}{|c|}{ Waktu } & \multicolumn{1}{c|}{ Status } & \multicolumn{1}{c|}{ Jenis } \\
\hline 1 & Novi Budianto & 20 Maret 2016 & Pemusik Demung Kiai Kanjeng & Primer \\
\hline 2 & Setyaji Dewanto & 12 Maret 2016 & Pemusik Drum Kiai Kanjeng & Primer \\
\hline 3 & Joko S. P & 14 Maret 2016 & Gitaris Kiai Kanjeng & Primer \\
\hline 4 & Joko Kamto & 11 Maret 2016 & $\begin{array}{l}\text { Pemusik Demung dan Rebbana Kiai } \\
\text { Kanjeng }\end{array}$ & Primer \\
\hline 5 & Helmi Mustofa & $\begin{array}{l}\text { 20 Mei 2015 dan } \\
5 \text { Maret 2016 }\end{array}$ & Manajer Kiai Kanjeng & Primer \\
\hline 6 & $\begin{array}{l}\text { Doni Johan Rudi } \\
\text { Saputro }\end{array}$ & 3 maret 2016 & $\begin{array}{l}\text { Koordinator Latihan dan Vokalis Kiai } \\
\text { Kanjeng }\end{array}$ & Primer \\
\hline 7 & Totok Raharjo & 28 Maret 2016 & Pendiri Kiai Kanjeng & Primer \\
\hline 8 & Bayu Kuncoro & 19 April 2015 & Pemusik Gendang Kiai Kanjeng. & Sekunder \\
\hline 10 & Ari Sumarsono & 21 November 2015 & Pemusik Biola Kiai Kanjeng & Sekunder \\
\hline 11 & Warsana & 2015 & Additionalplayer Kiai Kanjeng & Sekunder \\
\hline 12 & Yudistira & 25 Mei 2015 & Staf Manajer Kiai Kanjeng & Sekunder \\
\hline 13 & Muhammad Rossi & 22 Mei 2016 & Jemaah/Penonton Kiai Kanjeng & Sekunder \\
\hline 14 & Budi Yudo Saputro & 10 April 2016 & Jemaah/Penonton Kiai Kanjeng & Sekunder \\
\hline
\end{tabular}

Para narasumber tersebut cukup memperkuat data-data penelitian dari narasumber lainnya.

\section{b. Observasi}

Teknik ini adalah pengumpulan data dengan cara langsung mengamati obyek penelitian di lapangan, baik ketika proses latihan, pementasan, memimpin diskusi dalam kelompok dan lainnya.

Tabel 1.2 Subyek Penelitian berupa Observasi

\begin{tabular}{|l|l|l|}
\hline No & \multicolumn{1}{|c|}{ Tempat/Acara } & \multicolumn{1}{|c|}{ Waktu } \\
\hline 1 & Perpustakanaan Emha Ainun Nadjib. & 14 April 2016 \\
\hline 2 & Pembukaan MTQ Kabupaten Bantul. & 2015 \\
\hline 3 & Pengajian di Jalan Parangtritis. & 4 September 2015 \\
\hline 4 & $\begin{array}{l}\text { Macopat Syafa'at, "Mukhtamar Nahdatul Muhammadiyin” Tamantirto, } \\
\text { Bantul. }\end{array}$ & 17 Agustus 2015 \\
\hline 5 & Pengajian bulanan setiap tanggal 17 Macopat Syafaat. & 17 September 2015 \\
\hline 6 & $\begin{array}{l}\text { "Sinau Bareng Cak Nun dan Kiai Kanjeng” Diesnatalis STIMIK } \\
\text { AMIKOM. }\end{array}$ & 12 September 2015 \\
\hline
\end{tabular}


Hasil data penelitian yang dikumpulkan melalui wawancara dengan beberapa narasumber, observasi, dan dokumentasi kemudian direduksi dan dianalisis menggunakan teori yang digunakan.

Dalam proses reduksi, peneliti akan membuat rangkuman, menyajikan data dalam satuan-satuan jenis, pemilihan data berdasarkan tingkat relavansi yang kaitannya dengan setiap kelompok data dan mengkode data yang telah didapat di lapangan. Selanjutnya dilakukan pembahasan guna menjawab rumusan masalah yang diajukan oleh peneliti.

\section{Hasil dan Pembahasan}

\section{A. Analisis dan Pembahasan Gaya Kepemimpinan Cak Nuun \\ 1. Dalam Latihan Musik}

Proses latihan adalah suatu hal yang sangat menentukan berhasil atau tidak sebuha pementasan musik, berhasil secara sosial maupun scara profit. Termasuk Kiai Kanjeng sebagai kelompok yang memerlukan latihan dalam bermusik (hard skill), maupun latihan secara soft skill (motivasi, emosional, rasa, dan sebagainya). Dalam hal ini Cak Nun tidak menentukan orang yang bertindak sebagai koordinator latihan, namun para personil Kiai Kanjeng menentukan vokalis mereka Doni Johan Rudi Saputro sebagai koordinator latihan. Helmi Mustofa menambahkan Cak Nun mengikuti sistem yang ada, ia hanya berperan menghidupkan sistem itu saja. Kecenderungan gaya Cak Nun di sini adalah Transformasional.

a. Penjadwalan dan Durasi Latihan

"Penentuan jadwal latihan dan durasi merupakan kesepakatan para pemusik Kiai Kanjeng. Cak Nun mengikuti kesepakatan mekanisme penjadwalan durasi latihan tersebut secara sepenuh", kata Doni Johan Rudi Saputro. Apabila ada personil yang tidak bisa hadir dengan berbagai alasan, maka latihan akan dijadwalkan ulang. Adapun jadwal rutin latihan biasanya setiap hari Selasa dan Jumat dan berdurasi empat jam dari pukul 14.00 WIB hingga 24.00 WIB. Jadwal serta durasi ini bisa berubah tergantung kebutuhan para anggota. Ada dua sikap Cak Nun dalam penjadwalan dan penentuan durasi latihan. Sikap pertama menyerahkan keputusan kepada anggota. Sikap dan tindakan kedua adalah menghormati serta melaksanakan keputusan tersebut. Sikap pertama adalah ciri dari gaya kepemimpinan kendali bebas (Laissez Faire). Sedangkan sikap kedua adalah ciri gaya kepemimpinan transformasional.

\section{b. Kedisiplinan Anggota}

Menurut Doni dalam kelompok Kiai Kanjeng, keterlambatan personil dalam latihan bukan sesuatu yang dipermasalahkan dan tidak ada hukuman oleh siapapun, termasuk oleh Cak Nun sendiri sebagai pemimpin. Bagi Cak Nun dan anggota yang lain keterlambatan dalam latihan adalah suatu hal yang dapat dimaklumi. "Kedisiplinan Kiai Kanjeng bukanlah ketepatan waktu dalam latihan, tapi merupakan semangat yang harus dipertahankan dalam berkarya dan mencari hakikat sebuah karya", kata Helmi Mustofa. Peneliti melihat sikap Cak Nun dalam menanggapi keterlambatan pemusik dan vokalis dalam latihan sebagai berikut:

- Kedisiplinan bukan ketepatan hadir dalam latihan. 
- Memaklumi personil yang datang terlambat dengan alasan yang jelas.

- Cak Nun tidak peduli keterlambatan pemusik maupun vokalis dalam latihan.

- Cak Nun tidak ikut ambil bagian dalam keterlambatan latihan.

Maka dalam kedisiplinan latihan Cak Nun cenderung menerapkan gaya kepemimpinan kendali bebas (Laissez Faire).

c. Proses Pengkaryaan

1) Penentuan Repertoar

"Cak Nun sebagai pemimpin sangat terbuka kepada ide-ide yang disampaikan pemusik dan penyanyi Kiai Kanjeng. Ide karya tak hanya bersumber dari Cak Nun sendiri. Ada saat Cak Nun melontarkan pemikirannya untuk didiskusikan namun ada juga saat ia memberi instruksi, tergantung situasi dan kondisi yang dihadapi”, kata Bayu Kuncoro.

Menurut S.P Joko dan Totok Raharjo Ide kerya terkadang dari seorang anggota kemudian diajukan kepada anggota-anggota yang lain untuk diterjemahkan dan diintrepetasikan bersama-sama. Dapat disimpulkan bahwa ide karya dapat disampaikan oleh siapa saja.

Perilaku Cak Nun yang dapat digarisbawahi dalam penentuan karya adalah sebagai berikut :

1. Cak Nun menentukan sendiri ide karya kemudian teknis pelaksanaannya diserahkan kepada anggota.

2. Memberikan arahan atau instruksi kepada anggota.

3. Mengakomodir ide-ide dari angggota.

4. Mendiskusikan ide-ide yang ada dengan anggota.

Perilaku Cak Nun di atas pada poin pertama dan kedua menunjukkan ia adalah pemimpin yang inspiratif. Pemimpin yang bisa mendorong dan megarahkan juga memotivasi para anggotanya dalam berkarya. Ini adalah ciri dari gaya kepemimpinan transformasional.

Pada poin ketiga dan keempat, menerima ide dan selalu mendiskusikan ide-ide dengan anggota menunjukkan ciri gaya kepemimpinan partisipatif.

Dapat ditarik kesimpulan gaya kepemimpinan dalam aktifitas ini adalah gaya kepemimpinan partisipatif dan transformasional.

2) Proses Aransemen/Komposisi

Pada proses bermusik Kiai Kanjeng yang mengaransemen bisa satu orang atau lebih, misalnya lagu salawat badar, diaransemen oleh hampir semua pemusik Kiai Kanjeng. Meskipun kadang ide awalnya berasal dari Cak Nun sendiri.

"Saat seorang anggota mengaransemen suatu lagu, notasi yang telah ditulis kemudian dibagikan kepada anggota lain. Setelah itu, notasi tersebut bisa berubah tergantung keinginan anggota yang lain. Jadi, meski awalnya suatu lagu hanya diaransemen oleh satu orang, pada akhirnya semua anggota bisa terlibat.”, kata Setyaji Dewanto. Ada beberapa hal yang dapat digarisbawahi pada proses aransemen/komposisi lagu-lagu Kiai Kanjeng, yaitu:

- kesempatan mengembangkan diri anggota,

- kesempatan anggota bertanggung jawab dengan tugas,

- adanya dukungan pemimpin terhadap anggota dalam berkarya,

- terakomodirnya masukan dari anggota,

- meningkatnya kepercayaan diri anggota dalam berkarya. 
Berdasarkan beberapa poin-poin tersebut dapat disimpulkan bahwa Cak Nun menggunakan gaya kepemimpinan partisipatif. Memberikan anggota kesempatan untuk mengembangkan diri (poin pertama) dan dukungan Cak Nun kepada anggota Kiai Kanjeng dalam bekarya (poin ketiga) berarti seorang pemimpin mendorong dan memotivasi anggota Dua hal tersebut menunjukkan Cak Nun adalah seorang pemimpin inovatif. Adapun kesempatan bertanggung jawab dengan tugas yang dimiliki oleh anggota (poin kedua) menunjukkan adanya pengakuan Cak Nun akan pentingnya keberadaan anggota. Pengakuan seperti itu merupakan tanda penghormatan dari pemimpin kepada anggotanya.

Adanya penghormatan dan sifat inovatif adalah ciri dari gaya kepemimpinan transformasional.

Tabel 1.3 Gaya Kepemimpinan Cak Nun dalam Latihan Musik

\begin{tabular}{|c|c|c|c|c|}
\hline No & Kegiatan & Sikap/Perilaku/Tindakan & Ciri & Gaya Kepemimpinan \\
\hline \multirow[t]{2}{*}{1} & \multirow{2}{*}{$\begin{array}{l}\text { Penjadwalan } \\
\text { dan penentuan } \\
\text { durasi latihan }\end{array}$} & $\begin{array}{l}\text { 1. Menyerahkan segala } \\
\text { keputusan kepada anggota }\end{array}$ & $\begin{array}{l}\text { Tidak mencampuri dan } \\
\text { membiarkan }\end{array}$ & Kendali bebas \\
\hline & & $\begin{array}{l}\text { 2. Menghormati dan } \\
\text { melaksanakan keputusan }\end{array}$ & $\begin{array}{l}\text { Penghormatan kepada } \\
\text { anggota menjadi bentuk } \\
\text { motivasi }\end{array}$ & Transformasional \\
\hline \multirow[t]{3}{*}{2} & \multirow[t]{3}{*}{$\begin{array}{l}\text { Kedispilinan } \\
\text { Anggota }\end{array}$} & $\begin{array}{l}\text { 1. Kemakluman terhadap } \\
\text { keterlambatan }\end{array}$ & \multirow{3}{*}{$\begin{array}{l}\text { Tidak mencampuri dan } \\
\text { membiarkan }\end{array}$} & \multirow{3}{*}{ Kendali bebas } \\
\hline & & $\begin{array}{l}\text { 2. Tidak ambil bagian dalam } \\
\text { menindak atau menyikapi } \\
\text { personel yang terlambat }\end{array}$ & & \\
\hline & & $\begin{array}{l}\text { 3. Memiliki perspektif bahwa } \\
\text { disiplin itu bukan soal } \\
\text { waktu }\end{array}$ & & \\
\hline \multirow[t]{10}{*}{3} & \multicolumn{4}{|c|}{ Proses Pengkaryaan } \\
\hline & \multirow[t]{4}{*}{$\begin{array}{l}\text { a. Penentuan } \\
\text { Repertoar }\end{array}$} & $\begin{array}{l}\text { 1. Menentukan sendiri ide } \\
\text { karya }\end{array}$ & Inspiratif & Transformasional \\
\hline & & $\begin{array}{l}\text { 2. Memberikan arahan atau } \\
\text { instruksi }\end{array}$ & Motivatif, membimbing & Transformasional \\
\hline & & $\begin{array}{l}\text { 3. Mengakomodir ide-ide dari } \\
\text { anggota }\end{array}$ & $\begin{array}{l}\text { Akomodatif dan } \\
\text { menghargai anggota }\end{array}$ & $\begin{array}{l}\text { Parisipatif dan } \\
\text { Tansformasional }\end{array}$ \\
\hline & & $\begin{array}{l}\text { 4. Mendiskusikan ide-ide yang } \\
\text { ada dengan anggota }\end{array}$ & $\begin{array}{l}\text { partisipatif dan } \\
\text { menunjukkan rasa } \\
\text { hormat pada anggota }\end{array}$ & $\begin{array}{l}\text { Partisipatif dan } \\
\text { Transformasional }\end{array}$ \\
\hline & \multirow{5}{*}{$\begin{array}{l}\text { b. Proses } \\
\text { aransemen } / \mathrm{k} \\
\text { omposisi }\end{array}$} & $\begin{array}{l}\text { 1. Mengembangkan } \\
\text { kemampuan anggota }\end{array}$ & Inovatif & Transformasional \\
\hline & & $\begin{array}{l}\text { 2. Memberikan kesempatan } \\
\text { anggota untuk bertanggung } \\
\text { jawab terhadap tugas }\end{array}$ & $\begin{array}{l}\text { Pengakuan terhadap } \\
\text { keberadaan anggota }\end{array}$ & Transformasional \\
\hline & & $\begin{array}{l}\text { 3. Memberikan dukungan } \\
\text { kepada anggota }\end{array}$ & Motivatif & $\begin{array}{l}\text { Partisipatif dan } \\
\text { Transformasional }\end{array}$ \\
\hline & & $\begin{array}{l}\text { 4. Mengakomodir masukan/ide } \\
\text { dari anggota }\end{array}$ & $\begin{array}{l}\text { Akomodatif dan } \\
\text { Penghormatan terhadap } \\
\text { anggota }\end{array}$ & Transformasional \\
\hline & & $\begin{array}{l}\text { 5. Meningkatkan kepercayaan } \\
\text { diri anggota dalam berkarya }\end{array}$ & Motivatif & Transformasional \\
\hline
\end{tabular}




\section{Keputusan dalam Menyikapi Undangan Pementasan}

Keputusan menerima atau tidaknya undangan pentas sepenuhnya kewenanganan Cak Nun. Meski sepenuhnya menjadi otoritas Cak Nun, suatu undangan pementasan akan diterima dengan pertimbangan-pertimbangan tertentu. Seperti yang diutarakan oleh Helmi Mustofa, salah satu staf manajer Progres, Manajemen Kiai Kanjeng bahwa Cak Nun tidak menerapkan uang sebagai standar untuk memenuhi suatu undangan pementasan, namun berdasarkan kebutuhan sosial, misalnya untuk menyelesaikan konflik antarsuku, agama, ideologi dan lainnya. Helmi menambahkan bahwa biasanya yang menjadi pertimbangan Cak Nun dalam menerima suatu undangan pementasan ada beberapa hal, seperti:

- bentuk acaranya mengandung nilai sosial, misalnya,

- undangan pementasan akan dipenuhi apabila tujuan acara itu jelas,

- kelayakan Kiai dan kemanfaatan Kiai Kanjeng memenuhi undangan dan,

- kepentingan acara tersebut harus jelas.

Secara praktis kriteria menerima undangan pementasan menurut Novi Budianto juga yang menentukan adalah Cak Nun. "Kriteria tersebut seperti acara tidak ditiketkan (gratis), panggung harus rendah (agar lebih komunikatif dengan audien), tidak ada hubungan dengan partai politik (misalnya kampanye pilkada) dan audiens diberi lampu untuk penerangan.", kata Novi Budianto.

Novi Budianto menegaskan bahwa undangan mungkin tidak dikonsultasikan dengan Cak Nun apabila kriteria sudah terpenuhi sesuai yang ditetapkan oleh Cak Nun sendiri, sehingga dapat dipastikan Cak Nun menyetujui undangan tersebut. Kewenangan sepihak dari pemimpin itu adalah salah satu indikiator gaya kepemimpinan otokrasi namun dalam pengambilan keputusan memenuhi atau tidaknya undangan pementasan Kiai Kanjeng banyak indikator otokrasi yang tidak terpenuhi karena:

- Anggota mematuhi keputusan Cak Nun tanpa paksaan dengan ancaman psikologi, emosional dan fisik,

- Anggota boleh menanyakan alasan Cak Nun dalam memenuhi atau menolak undangan pementasan,

- Anggota mengetahui bahan/penilaian yang dijadikan pertimbangan Cak Nun dalam mengambil keputusan dalam memenuhi atau menolak undangan pementasan.

Gaya kepemimpinan Cak Nun dalam hal ini tidak bisa dikategorikan otokrasi secara utuh. Atas pertimbangan tersebut, maka peneliti menyimpulkan gaya ini adalah gaya kepemimpinan semi otokrasi (setengah otokrasi). Namun di luar gaya kepemimpinan di atas, Cak Nun juga menerapkan gaya kepemimpinan transformasional dengan ciri kharismatik. Kharismatik Cak Nun dapat dilihat dari:

- Keputusan Cak Nun diterima, dipatuhi secara rela dan ikhlas oleh pemusik, vokalis serta staf,

- Komunikasi Cak Nun yang jelas serta dapat dimengerti oleh seluruh seluruh pemusik,vokalis dan staf,

- Pemusik, vokalis dan staf menganggap bahwa penilaian yang dijadikan Cak Nun dalam menyikapi undangan pementasan adalah sebuah kebenaran yang mutlak.

Peneliti menganalisa bahwa Cak Nun menggunakan dua (kombinasi) gaya kepemimpinan dalam hal menyikapi undangan pementasan. Menurut peneliti gaya 
kepemimpinan Cak Nun dalam hal ini dengan melihat indikator di atas dapat dikategorikan sebagai gaya kepemimpinan otokrasi-transformasional (kharismatik).

\section{Tabel 1.4. Gaya Kepemimpinan Cak Nun Dalam Menyikapi Undangan}

\begin{tabular}{|l|l|l|l|}
\hline \multicolumn{1}{|c|}{ Kegiatan } & \multicolumn{1}{|c|}{ Sikap/Perilaku/Tindakan } & \multicolumn{1}{c|}{ Ciri } & \multicolumn{1}{c|}{ Gaya } \\
\hline $\begin{array}{l}\text { Menyikapi } \\
\text { undangan }\end{array}$ & $\begin{array}{l}\text { Memutuskan dan menentukan kiteria } \\
\text { diterima atau tidaknya suatu undangan } \\
\text { pentas. }\end{array}$ & $\begin{array}{l}\text { Kewenangan mutlak } \\
\text { para anggota sukarela } \\
\text { menerima setiap } \\
\text { keputusan. }\end{array}$ & Otokrasi- \\
& & $\begin{array}{l}\text { Transformasional } \\
\text { Papa anggota meyakini }\end{array}$ & \\
& & apun keputusan yang \\
& & diambil merupakan yang & \\
terbaik (Kharismatik). & \\
\hline
\end{tabular}

\section{Pengembangan Sumber Daya Manusia}

a. Kemampuan Staf

Menurut Doni Johan Rudi Saputro pengembangan kemampuan Staf secara khusus belum pernah dilakukan. "Kemampuan Staf adalah sesuatu yang langsung dari alam, otodidak dan belajar dari pengalaman." Kata Doni Jihan Rudi Saputro.

Helmi Mustofa menambahkan bahwa kemampuan Staf tidak dilakukan karena Kiai Kanjeng bukanlah sebuah organisasi kelembagaan yang menggunakan aturan-aturan khusus seperti anggaran dasar (AD)/anggaran rumah tangga (ART) dan pengembangan kemampuan kestafan adalah sesuatu yang alamiah tanpa ada peran Cak Nun di dalamnya.

Dalam hal ini Cak Nun tidak berperan mengarahkan para stafnya belajar khusus tentang menejerial dalam sebuah kelompok. Secara penuh staf dipersilahkan mengembangkan kemampuannya oleh Cak Nun. Maka gaya kepemimpinan Cak Nun dalam hal pengembangan kemampuan staf adalah kendali bebas (Laissez Faire).

b. Kemampuan Pemusik dan Vokalis

Pada dasarnya para pemusik dan vokalis Kiai Kanjeng tidak merencanakan khusus pelatihan aliran musik tertentu, karena sejak awal bergabung dengan Kiai Kanjeng para pemusik sudah mempunyai kemampuan musikalitas yang baik dengan latar belakang musik yang beragam, tradisi mapun barat. Totok Raharjo menambahkan pengembangan bermusik pemusik Kiai Kanjeng biasanya dari latihan rutin, mengapresiasi dan belajar referensi musik apa saja salah satunya melalui Youtube. Hal serupa disampaikan oleh Bayu Kuncoro dan Setyaji Dewanto bahwa sebagai kelompok musik yang membawakan berbagai macam aliran musik, maka dari itu pemusik Kiai Kanjeng sangat memerlukan peningkatan kemampuan bermusik. Misalnya mengadakan pelatihan rebana Jombang dan rebana al-Banjari yang dilatih oleh Ramli. Pelatihan rebbana tersebut diusulkan oleh pemusik Kiai Kanjeng dan Cak Nun. Helmi Mustofa dan S.P Joko menyampaikan keterangan yang senada bahwa suatu ketika seorang etnomusikolog dari Amerika, Aniras Musen, melakukan penelitian tentang perempuan dan musik Islam di Indonesia, salah satu obyek penelitian musik Islam adalah Kiai Kanjeng. Melihat kesempatan tersebut, pemusik Kiai Kanjeng meminta Aniras Musen untuk melatih mereka memperdalam musik Timur Tengah dalam sebuah workshop yang dilaksanakan oleh mereka sendiri. Ide pelatihan tersebut berasal dari Cak Nun meminta para pemusik Kiai Kanjeng untuk belajar musik Timur Tengah kepada Aniras Musen dalam 
bentuk workshop. Doni Johan Rudi Saputro menerangkan bahwa dalam pengembangan kemampuan musik karawitan Jawa, pemusik Kiai Kanjeng hingga sekarang dilatih secara khusus dan mendalam oleh dua orang personil mereka sendiri Gianto dan Arianto. Gianto dan Arianto adalah pemain saron yang pernah bersekolah khusus pendidikan karawitan. Pelatihan khusus Kiai Kanjeng memperdalam musik Kawaritan Jawa tersebut merupakan usulan oleh para personil.

Peneliti dapat menyimpulkan bahwa Cak Nun cenderung membebaskan para pemusik dan vokalis Kiai Kanjeng mengembangkan kemampuannya dengan berbagi cara. Cak Nun hanya meminta pemusik dan vokalis untuk terus belajar aliran musik apa saja. Karena mereka dianggap oleh Cak Nun sudah mumpuni dan mempunyai modal bermusik yang baik walaupun berangkat dari latar belakang musik yang berbeda-beda. Namun selain itu Cak Nun kadang mendatangkan atau meminta ahli dalam bidang tertentu baik dari luar maupun dari dalam Kiai Kanjeng sendiri memberi pembelajaran musik tertentu kepada pemusik dan vokalis.

Salah satu cara yang pernah diterapkan oleh Cak Nun untuk mengembangkan kemampuan bemusik adalah memberikan pelatihan singkat kepada pemusik Kiai Kanjeng dengan mendatangkan para ahli di bidangnya masing-masing.

Ada beberapa poin yang dapat diambil dengan adanya kegiatan pelatihan tersebut, yaitu:

- Cak Nun sebagai pemimpin memiliki perhatian terhadap kebutuhan anggota,

- Adanya usaha dari Cak Nun untuk mengembangkan kemampuan bermusik anggota,

- Cak Nun membuka kesempatan anggota Kiai Kanjeng untuk mengembangkan diri dalam bermusik dan,

- Cak Nun mendorong anggota Kiai Kanjeng untuk meningkatkan kemampuan bermusik.

Perhatian terhadap kebutuhan anggota adalah salah satu indikator gaya kepemimpinan transformasional. Cak Nun mendorong pemusik dan vokalis Kiai Kanjeng untuk meningkatkan kemampuan adalah indikator gaya transformasional. Sesuai apa yang dikemukakan M. Bernard Bass bahwa pemimpin mendorong dan memotivasi para anggota untuk melakukan sesuatu yang melebihi kemampuan mereka sendiri untuk menyejahterakan kelompok (Lako, 2004: 92).

Sedangkan usaha mengembangkan kemampuan dan membuka kesempatan anggota untuk memngembangkan kemampuan adalah salah satu indikator gaya kepemimpinan partisipatif. Cak Nun dalam mengembangkan kemampuan pemusik tidak hanya menggunakan satu gaya kepemimpinan, tapi beberapa gaya kepemimpinan. Karena itu, maka peneliti mengkategorikan gaya kepemimpinan Cak Nun dalam pengembangan kemampuan pemusik adalah gaya kepemimpinan kombinasi yaitu: gaya kepemimpinan partisipatiftransformasional.

Tabel 1.5 Gaya Kepemimpinan Cak Nun untuk Pengembangan Sumber Daya Manusia

\begin{tabular}{|l|l|l|l|l|}
\hline No & \multicolumn{1}{|c|}{ Kegiatan } & Sikap/Perilaku/Tindakan & \multicolumn{1}{c|}{ Ciri } & \multicolumn{1}{c|}{ Gaya } \\
\hline 1. & $\begin{array}{l}\text { Pengembangan } \\
\text { SDM staf } \\
\text { (manajerial) }\end{array}$ & $\begin{array}{l}\text { Menyerahkan sepenuhnya } \\
\text { kepada anggota. }\end{array}$ & $\begin{array}{l}\text { Membiarkan anggota } \\
\text { bergerak sendiri. }\end{array}$ & Kendali bebas \\
\hline
\end{tabular}




\begin{tabular}{|l|l|l|l|l|}
\hline 2. & $\begin{array}{l}\text { Pengembangan } \\
\text { SDM Pemusik } \\
\text { dan vokalis }\end{array}$ & $\begin{array}{l}\text { Mendorong anggota untuk } \\
\text { mengembangkan diri. }\end{array}$ & $\begin{array}{l}\text { Motivasi dan membuka } \\
\text { peluang untuk anggota } \\
\text { dalam mengembangkan } \\
\text { diri. }\end{array}$ & $\begin{array}{l}\text { Partisipatif- } \\
\text { transformasional }\end{array}$ \\
\hline
\end{tabular}

\section{Dalam Pementasan}

\section{a. Persiapan Briefing}

Sebelum pementasan, biasanya Cak Nun memberi arahan singkat terlebih dahulu mengenai materi komposisi dan lagu yang akan dimainkan. Pemilihan lagu yang dimainkan pun dilakukan dan diputuskan sendiri oleh Cak Nun. Para pemusik Kiai Kanjeng meyakini apa pun yang diputuskan oleh Cak Nun adalah yang terbaik. Hal ini karena mereka mempercayai sebagai pemimpin, Cak Nun adalah orang yang paling memiliki kapabilitas mempertimbangkan lagu dan komposisi yang sesuai dengan kondisi acara di mana Kiai Kanjeng akan tampil.

Helmi Mustofa menambahkan bahawa Cak Nun pada saat menjelang pementasan akan menggambarkan situasi dan kondisi pementasan kepada Kiai Kanjeng, lalu dipelajari dengan singkat untuk menentukan daftar lagu yang akan ditembangkan. Sebelum memberi arahan dan mengambil keputusan, situasi dan kondisi seperti keaadan sound, lampu, ruang panggung, kapasitas penonton biasanya disampaikan oleh anggota Kiai Kanjeng. Setelah itu, baru Cak Nun menyimpulkan, memberi arahan, dan mengambil keputusan.

Setyaji Dewanto menerangkan bahwa sebelum pementasan, Cak Nun biasa memberi arahan secara langsung. Apabila Cak Nun belum atau tidak berada di tempat, para anggota konsultasi melalui aplikasi penyampai pesan.

Tidak menutup kemungkinan pada suatu acara, Kiai Kanjeng sudah menyiapkan beberapa nomor lagu, namun sewaktu pementasan, lagu-lagu yang sudah disiapkan tersebut diganti dengan lagu yang berbeda oleh Cak Nun. Hal itu menurut Helmi sesuai dengan situasi dan dinamika yang berlangsung saat itu. Ketika hal itu terjadi ujar Helmi, tak ada kekecewaan di antara pemusik terhadap sikap Cak Nun tersebut. Semuanya menerima dengan ihklas karena percaya bahwa Cak Nun memiliki kemampuan membaca situasi, sehingga mengetahui lagu apa yang paling sesuai dengan kondisi dan dinamika saat itu, (selama pementasan). Pengarahan singkat sebelum pementasan pelaksanaanya tidak rutin, karena semua tergantung permintaann Cak Nun. Semua keputusan dalam pengarahan singkat tersebut sangat diterima oleh pemain musik Kiai kanjeng.

Melihat data yang diperoleh, penulis menyimpulkan bahwa dalam persiapan pementasan ini dapat ditarik beberapa poin, yaitu :

- Cak Nun memegang kewenangan dalam mengambil keputusan (misalnya daftar tembang lagu),

- Para anggota Kiai Kanjeng menerima keputusan dengan keyakinan bahwa keputusan itu adalah keputusan yang terbaik bagi Kiai Kanjeng dan penonton,

- Cak Nun menerima masukan data mengenai tempat pementasan dari pemusik Kia Kanjeng sendiri untuk dijadikan bahan memppertimbangkan keputusan,

- Keyakinan anggota Kiai Kanjeng terhadap keputusan Cak Nun karena Kharisma Cak Nun di mata anggotanya. 
Pada poin pertama dan kedua memperlihatkan Cak Nun menerapkan dua gaya kepemimpinan, yaitu otokrasi dan transformasional. Otokrasi karena keputusan tentang tembang yang akan dimainkan merupakan kewenangan mutlak Cak Nun dan transformasional karena apa pun yang diputuskan Cak Nun akan diterima dengan ikhlas oleh anggota berdasarkan kharisma yang dimiliki Cak Nun. Namun poin ketiga menunjukan Cak Nun menerapkan gaya kepemimpinan demokratis. Karena merima masukan data lapangan sebelum pementasan dimulai.

Peneliti tidak dapat menyimpulkan bahwa dalam persiapan pementasan ini Cak Nun menggunakan kombinasi antara gaya kepemimpinan otokrasi dan transformasional karena pada gaya otokrasi hanya satu ciri khas yang terpenuhi. Misalnya, meski memiliki kewenangannya mutlak, tetapi Cak Nun tidak memaksakan keputusannya dengan ancaman.

Maka dari itu peneliti menyebut gaya kepemimpinan Cak Nun dalam persiapan dan pengarahan singkat sebelum pementasan adalah semi otokrasi-transformasional dan demokratis.

\section{b. Pementasan (On Stage)}

Sebagai pemimpin Kiai Kanjeng, Cak Nun memegang kendali secara penuh ketika Kiai Kanjeng tengah dalam pementasan, di Yogyakarta dan sekitarnya maupun di luar daerah, baik berupa instruksi atau berupa permintaan tolong kepada pemusik. Para pemusik dan para vokalis dengan sangat sedia menunggu kapan dan lagu apa yang harus dilantunkan untuk para jemaah pengajian (umumnya). Kiai Kanjeng pentas pada pengajian Maiyah (Macopat Syafa'at) yang diselenggarakan setiap satu kali dalam sebulan, di Tamantirto, Kecamatan Banguntapan, Kabupaten Bantul misalnya, Cak Nun tidak hanya memimpin Kiai Kanjeng bermusik untuk menghibur jemaah, namun juga sebagai pembicara sekaligus mediator dalam diskusi dan dialog dengan jemaah.

Novi Budianto menyatakan bahwa saat pementasan berlangsung, Cak Nun menentukan tembang. Para pemusik hanya bersiap-siap melaksanakan perintah Cak Nun. Hal serupa disampaikan Totok Raharjo bahwa pada pementasan, untuk pemilihan nomor lagu, anggota Kiai Kanjeng hanya memberikan nomor-nomor lagu, sedangkan yang menentukan lagu apa yang dimainkan di pementasan adalah Cak Nun. Doni Johan Rudi Saputro menegaskan "Pimpinan, sutradaraya mbah Nun (Cak Nun). Mbah Nun itu udah punya skenario dalam suatu acara. Kita kasih data-data, Mbah Nun yang menyusun, kemudian kita ikut skenarionya Mbah Nun.

Dalam acara lain juga demikian, Cak Nun bertindak sebagai pemimpin Kiai Kanjeng dan sebagai mediator dalam diskusi dengan para jamaah.

\section{1) Menentukan Tembang}

Ari Sumarsono menerangkan bahwa sewatu pementasan, Cak Nun adalah orang yang menentukan tembang yang dimainkan. Tak jarang lagu-lagu yang sudah dipersiapkan urung dimainkan karena Cak Nun mengganti lagu-lagu tersebut dengan lagu-lagu lain yang dinilai Cak Nun sesuai dengan kondisi acara dan waktu saat pementasan berlangsung. Ketika hal itu terjadi pemusik tidak pernah mempermasalahkan penggantian lagu yang tiba-tiba. Karena pemusik dan vokalis menganggap Cak Nun adalah orang yang sangat faham dengan kesesuaian tembang lagu tertentu dengan kondisi para penonton dalam hal ini jamaah.

Setyaji Dewanto menegaskan perubahan lagu yang akan dimainkan secara tiba-tiba sering terjadi saat pementasan berlangsung. "Bisa sekali berubah (lagu yang akan dimainkan- 
peneliti). Bahkan lagu yang disiapkan sering tidak dimainkan. Lagu yang sudah lama tidak dimainkan tiba-tiba dimunculkan, maka teman-teman bersikap harus bisa. Sami'na wa ata'na (mendengar dan menaati). Tapi Cak Nun sudah ngukur, mengetahui bahwa anggota Kiai Kanjeng bisa memainkan lagu yang akan dimainkan”.

Ketika dalam acara bulanan "Macopat Syafa'at" pada 17 September 2015, peneliti mengamati Cak Nun meminta kepada Imam yang bertindak sebagai vokalis mempersilahkan untuk memilih salah satu di antara dua lagu yang akan dibawakan, kemudian diskusi dengan para jemaah maiyah dilanjutkan. Namun setelah Kiai Kanjeng selesai memainkan satu tembang lagu, Cak Nun langsung meminta Imam mempersembahkan satu tembang lagu lagi dan Cak Nun yang menentukan tembang lagu yang akan dibawakan, yaitu "Renungkanlah". Dalam acara bulanan yang sama dengan tema "Mukhtamar Nahdatul Muhammadiyin" pada 17 Agustus 2015, Cak Nun selalu memberikan instruksi kepada pemusik Kiai Kanjeng untuk terus siap (standby) di atas panggung pada saat diskusi berlangsung. Padahal pada saat itu ada pemusik yang menundukkan kepala karena letih.

Contoh lain dari pengamatan peneliti, bahwa ketika Kiai Kanjeng pentas dalam acara Halal bi Halal Akbar dengan tema "Tafakur Akhir Zaman" Cak Nun yang pada saat itu bertindak sebagai pemberi materi dan moderator, secara tiba-tiba menyuruh Imam Fatawi (vokalis) untuk membawakan sebuah lagu tanpa meminta pertimbangan dari Imam dan pemusik lain.

Peneliti menyimpulkan sewaktu pementasan Cak Nun cenderung menggunakan gaya kepemimpinan otokrasi. Peneliti berpendapat demikian karena sewaktu pemetasan, penentuan tembang juga merupakan kewenangan Cak Nun; Cak Nun sering mengganti tembangtembang yang sudah dipersiapkan oleh Kiai Kanjeng secara mendadak dan sesuai dengan keinginannya. Ia menuntut agar pemusik selalu siap tanpa memperhatikan kondisi fisik para pemusik tersebut.

Namun di sisi yang lain para anggota setuju secara mutlak dengan keputusan sepihak oleh Cak Nun tanpa merasa adanya paksaan, karena para anggota Kiai Kanjeng menganggap bahwa keputusan yang telah diambil Cak Nun adalah keputusan yang terbaik. Hal ini dapat peneliti simpulkan bahwa Cak Nun menerapkan gaya kepemimpinan transformasionnal. Karena Cak Nun memenuhi syarat pemimpin yang memiliki kharisma.

\section{2) Waktu Mulai Melantunkan Tembang}

Pementasan Kiai Kanjeng tak hanya soal pertunjukan musik, tapi juga ceramah dan diskusi dengan para jamaahnya. Tak jarang ada juga sesi tanya jawab. Hal inilah yang kemudian menjadi pertimbangan untuk mulai melantukan tembang, menghentikan tembang dan jumlah tembang yang harus dimainkan di sela-sela diskusi. Setelah sesi diskusi berlangsung cukup lama, Cak Nun meminta para pemusik Kiai Kanjeng untuk membawakan lagu Melayu. Lalu para pemusik dan vokalis Kiai Kanjeng terlihat seperti saling berkoordinasi. Contoh lain yang peneliti amati adalah ketika dalam acara halal bihalal dengan tema "Tafakur Akhir Zaman". Dalam acara ini para jemaah mengajukan beberapa pertanyaan kepada Cak Nun, namun sebelum Cak Nun menjawab pertanyaan-pertanyaan tersebut, ia meminta Kiai Kanjeng membawakan dua buah tembang lagu secara spontan.

Menurut Muhammad Rossi salah seorang audiens, musik Kiai Kanjeng lagu yang dilantunkan sangat tepat sasaran, karena dapat mengurangi kejenuhan dan rasa kantuk akibat diskusi yang panjang Hal yang serupa juga diamini oleh Yudo bahwa lagu-lagu yang 
dimainkan sangat sesuai dengan kondisinya sebagai penonton, terutama lagu yang berjudul shahibul baiti.

Dalam acara bulanan Macopat Syafaat 17 September 2015 pada sesi tanya jawab, Cak Nun mengatakan dengan jelas dan tegas bahwa, "sedikit menambahkan penjelasan sebelum membawakan dua buah tembang lagu". Waktu ketika ingin membawakan 2 buah tembang lagu tersebut Cak Nun tanpa berkoordinasi terlebih dahulu dengan para pemusik Kiai Kanjeng. Menurut Setyaji Dewanto, waktu mulai dan berhenti memainkan lagu sepenuhnya berada pada keputusan Cak Nun. Cak Nun bertindak sebagai moderator, pemimpin dan penentu meski kadang-kadang ia juga minta pendapat kepada anggota Kiai Kanjeng. Apabila ada masukan dari anggota, keputusan akhir tetap ada pada kewenangan Cak Nun. Hal serupa disampaikan oleh S.P Joko bahwa pada saat pementasan, Cak Nun berperan sebagai sutradara dan Imam. Waktu mulai dan berhenti memainkan suatu lagu pada pementasan tergantung pada keputusan Cak Nun.

Berdasarkan data di atas, peneliti menyimpulkan waktu mulai dan berhenti melantunkan tembang juga sepenuhnya menjadi kewenangan Cak Nun. Pada acara pementasan, biasanya tembang-tembang dimainkan disela-sela acara diskusi, ceramah atau pada sesi tanya jawab.

Saat Cak Nun meminta pemusik mulai memainkan suatu tembang, para pemusik meyakini bahwa saat itu adalah waktu yang tepat dalam memainkan tembang agar para jamaah tidak bosan. Kewenangan Cak Nun dan penerimaan keputusan oleh anggota Kiai Kanjeng berdasarkan kepercayaan bahwa Cak Nun memiliki kemampuan membaca situasi secara tepat - dalam hal ini menentukan waktu mulai atau berhenti memainkan suatu tembang - maka ada beberapa hal yang bisa ditarik kesimpulan, yaitu :

- Cak Nun memiliki kewenangan mutlak dan tanpa harus melibatkan anggota dalam mengambil keputusan.

- Para pemusik Kiai Kanjeng percaya bahwa keputusan Cak Nun tersebut adalah yang terbaik karena mereka menilai Cak Nun memiliki kemampuan membaca momentum yang tepat.

Melihat dari dua poin di atas, maka dapat digarisbawahi bahwa poin pertama adalah ciri karakteristik gaya kepemimpinan otokrasi dan poin kedua adalah ciri khas gaya kepemimpinan transformasional. Artinya sewaktu pementasan, gaya kepemimpinan Cak Nun merupakan gaya kombinasi antara gaya kepemimpinan otokrasi dan gaya kepemimpinan transformasional.

\section{c. Pascapementasan/Evaluasi}

Pascapementasan adalah waktu yang tepat untuk mengevaluasi segala kegiatan yang telah terlaksana. Kiai Kanjeng mengevaluasi pementasan yang terlaksana bertujuan agar segala kegiatan pementasan berikutnya berjalan lebih lancar. Proses evaluasi pascapementasan Kiai Kanjeng dilaksanakan baik secara langsung sesaat setelah pementasan, maupun beberapa hari kemudian. Kiai Kanjeng sering pentas pada malam hari, jadi evaluasi baik dilakukan malam setelah pentas atau pagi hari. Beberapa materi yang dievaluasi di antaranya terkait dengan pementasan yang telah dilaksanakan, yang akan dilaksanakan bahkan yang tidak ada hubungannya dengan pementasan. Evaluasi ini dilakukan oleh para pemusik dan vokalis saja dengan dan atau tanpa Cak Nun. Menurut Doni evaluasi setelah pementasan biasanya dilakukan dengan cara diskusi santai, seperti mengobrol biasa jika ada hal yang perlu untuk dibenahi. Pada saat itu Cak Nun memberikan pandangan-pandangan 
pementasan yang lalu agar pementasan berikutnya menjadi lebih baik. Doni mencontohkan Cak Nun memberikan arahan dalam masuk untuk memulai bernyanyi agar lebih tepat lagi. Hal tersebut bertujuan agar pesan lagu yang dibawakan sampai kepada penonton/jemaah. Namun untuk solusi secara teknis, Cak Nun menyerahkan kepadanya. "Ketika transisi kurang cepat, kamu masuknya kurang cepat, berarti rasanya juga kurang nyampe. Maksudnya salahmu di sini lo don!, salahmu di sini!. Ngasih tau, harusnya kamu gini, kui cubo kamu belajar, kamu temukan itu, solusinya gimana!".

Apabila Cak Nun tidak hadir dalam evaluasi, maka yang berperan dalam pengarahan evalusi bisa siapa saja bahkan tanpa ada penengah. Namun jika Cak Nun ikut serta dalam evaluasi, maka evaluasi dipimpin olehnya.

Doni menambahkan ketika Cak Nun memberikan kritikan atau penilaian pementasan, para pemusik dan vokalis menanggapinya dengan positif, tidak membantah, menerima dengan begitu saja dan senang. Karena para pemusik dan vokalis hal tersebut adalah sebagai motivasi untuk belajar lebih giat.

Menurut Yudistira, selain teknis dalam pementasan terkadang adalah sound sytem yang tidak stabil dan proses evaluasi tersebut yang memimpin adalah Cak Nun. Novi Budianto menjelaskan yang diamini oleh Setyaji Dewanto bahwa evaluasi setelah pementasan yang memberikan arahan tidak selalu Cak Nun, tapi semua anggota Kia Kanjeng bisa memberikan tanggapan dan usuluan. Proses evaluasi pun tak selalu harus dilaksanakan. Begitu juga tempat evaluasi, bisa di mana saja.

S.P Joko menambahkan terkadang pemusik/vokalis Kiai Kanjeng memberi kritikan terhadap Cak Nun atas pementasan yang telah dilaksanakan, misalnya terkait masalah Cak Nun bernyanyi. Namun Cak Nun menerima atas kritikan tersebut oleh anggota yang lain.

Dari data di atas ada beberapa hal yang peneliti dapat garis bawahi pada pascapementasan/evaluasi Kiai Kanjeng, yaitu:

- Cak Nun berperan sebagai pengarah, pembimbing dan motivator dalam proses evaluasi.

- Kalau Cak Nun tidak hadir, siapa pun boleh menjadi pemimpin dalam evaluasi.

- Ketika ada masalah sewaktu pementasan, biasanya Cak Nun memberi arahan agar anggotanya menemukan solusi sendiri.

- Cak Nun juga menerima kritikan dari para pemusik Kiai Kanjeng.

Pada poin pertama menunjukkan adanya peran Cak Nun memotivasi pemusik untuk memperbaiki kesalahan ketika pementasan. Maka dari itu, Cak Nun menggunakan gaya kepemimpinan transformasional. Pada poin kedua dan ketiga, ketidak hadiran Cak Nun dan meminta kepada pemusik untuk mencari solusi sendiri dalam mengavaluasi hasil pementasan menunjukan Cak Nun menerapkan gaya kepemimpinan kendali bebas (Laissez Faire). Sedangkan poin empat Cak Nun sebagai pemimpin menerima kritikan dari pemusik/vokalis adalah ciri dari gaya kepemimpinan demokratis, karena menurut Syamsul (2012) ciri kepemimpinan yang demokratis adalah pemimpin yang senang menerima saran, pendapat dan kritik dari anggota/bawahannya. Dalam hal tersebut Cak Nun memposisikan semua yang terlibat dalam kegiatan adalah tanggung jawab bersama sesuai dengan yang dimaksud dalam Nawawi dan Hadari (2012: 101). Jadi, dalam evaluasi pementasan Cak Nun menerapkan kombinasi gaya kepemimpinan, yaitu transformasional, kendali bebas (Laissez Faire) dan demokratis. 
Tabel 1.6 Gaya Kepemimpinan Cak Nun dalam Pementasan

\begin{tabular}{|c|c|c|c|}
\hline No & Kegiatan & Ciri & Gaya \\
\hline 1 & Persiapan (breafing) & $\begin{array}{l}\text { Mengakomodir data dan } \\
\text { keputusan mutlak Cak } \\
\text { Nun. }\end{array}$ & $\begin{array}{l}\text { Semi Otokrasi- } \\
\text { Transformasional } \\
\text { dan Demokratis }\end{array}$ \\
\hline \multirow[t]{4}{*}{2} & \multicolumn{3}{|l|}{ Pementasan (on stage) } \\
\hline & a. Menentukan tembang & $\begin{array}{l}\text { Kewenangan mutlak Cak } \\
\text { Nun dan dianggap yang } \\
\text { terbaik menurut anggota. }\end{array}$ & Otokrasi \\
\hline & $\begin{array}{l}\text { b. Waktu mulai dan berhenti } \\
\text { melantunkan tembang } \\
\text { (timing) }\end{array}$ & $\begin{array}{l}\text { Kewenangan mutlak Cak } \\
\text { Nun dan dianggap yang } \\
\text { terbaik menurut anggota. }\end{array}$ & $\begin{array}{l}\text { Otokrasi dan } \\
\text { Transformasional }\end{array}$ \\
\hline & c. Pascapementasan/evaluasi & $\begin{array}{l}\text { Membebaskan, menerima } \\
\text { masukan, dan } \\
\text { menginovasi. }\end{array}$ & $\begin{array}{l}\text { Transformasinal, } \\
\text { Kendali Bebas, dan } \\
\text { Demokratis. }\end{array}$ \\
\hline
\end{tabular}

Cak Nun menerapkan gaya kepemimpinan yang berbeda-beda dalam masing-masing situasi dan kondisi, yaitu otokrasi, demokratis, kendali bebas, paritispatif, dan transformasional. Secara keseluruhan, ada gaya kepemimpinan yang sama pada tiap proses, yaitu gaya kepemimpian transformasional.

\section{Kesimpulan}

Berdasarkan analisa data dalam penelitian ini, karakteristik gaya kepemimpinan yang identik dengan Cak Nun secara keseluruhan cenderung memenuhi katagori gaya kepemimpinan transformasional.

Gaya kepemimpinan Cak Nun dalam kelompok musik Kiai Kanjeng dapat berkelanjutan karena ia menerapkan gaya kepemimpinan yang berbeda-beda sesuai dengan aktivitas dan kegiatan Kiai Kanjeng sehingga berimplikasi pada kesolidan anggota, kreatif, eksistensi dan mempunyai penggemar yang militan sehingga Kiai Kanjeng mampu bertahan hingga sekarang.

Model gaya kepemimpinan Kiai Kanjeng yang dipimpin oleh Cak Nun menerapkan gaya kepemimpinan yang berbeda-beda, yaitu otokrasi, demokrasi, kendali bebas (laissez faire) dan partisipatif, tergantung pada aktivitas/kegiatan Kiai Kanjeng.

Berdasarkan kesimpulan dan analisis dari kasus yang telah dilakukan, saran yang dapat peneliti berikan demi kemajuan dunia akademik dan praktis, yaitu:

- Peneliti mengharapkan kepada peneliti selanjutnya untuk menyempurnakan penelitian ini di masa yang akan datang.

- Model gaya kepemimpinan yang telah dirumuskan dalam penelitian ini sangat cocok untuk kelompok Kiai Kanjeng. 


\section{Kepustakaan}

Cahyo, Nur Agus. 2014. Kebiasaan Sehari-hari Para Guru Bangsa, Cetakan ke-1, Yogyakarta; IRCiSoD.

Lako, Andreas. 2004. Kepemimpinan dan Kinerja Organisasi (Isu, Teori dan Solusi), Cetakan ke-1, Yogyakarta: Asmara Books.

Nawawi, Hadari dan Hadari, M. Martini. 2012. Kepemimpinan Yang Efektif, Cetakan ke-6, Yogyakarta; Gajah Mada Press.

Salam, Aprinus dkk. 2014. Kitab Ketentraman Dari Khasanah Emha Ainun Nadjib, Cetakan ke-1, Bekasi; Penjuru Ilmu Sejati.

Sutrisno, Edy. 2013. Manajemen Sumber Daya Manusian, Cetakan ke-5, Jakarta: Kencana.

Www.Caknun.com

www.Kiaikanjeng.com 